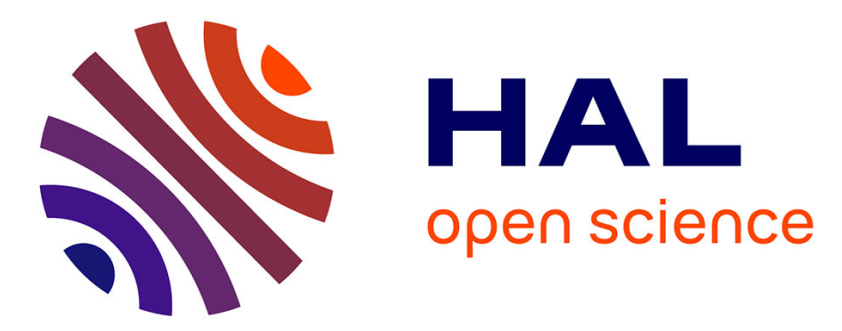

\title{
ACE gene insertion/deletion polymorphism and capillary permeability in hypertension
}

Giulia Dell'Omo, Giuseppe Penno, Laura Pucci, Daniela Lucchesi, Carmen Fotino, Stefano del Prato, Roberto Pedrinelli, Roberto Pedrinelli

\section{- To cite this version:}

Giulia Dell'Omo, Giuseppe Penno, Laura Pucci, Daniela Lucchesi, Carmen Fotino, et al.. ACE gene insertion/deletion polymorphism and capillary permeability in hypertension. Clinical Science, 2006, 111 (6), pp.357-364. 10.1042/CS20060165 . hal-00479331

\section{HAL Id: hal-00479331 \\ https://hal.science/hal-00479331}

Submitted on 30 Apr 2010

HAL is a multi-disciplinary open access archive for the deposit and dissemination of scientific research documents, whether they are published or not. The documents may come from teaching and research institutions in France or abroad, or from public or private research centers.
L'archive ouverte pluridisciplinaire HAL, est destinée au dépôt et à la diffusion de documents scientifiques de niveau recherche, publiés ou non, émanant des établissements d'enseignement et de recherche français ou étrangers, des laboratoires publics ou privés. 


\section{ACE GENE INSERTION/DELETION POLYMORPHISM MODULATES CAPILLARY PERMEABILITY IN HYPERTENSION}

Giulia Dell'Omo, Giuseppe Penno ${ }^{1}$, Laura Pucci ${ }^{1}$, Daniela Lucchesi ${ }^{1}$, Stefano Del Prato $^{1}$, Roberto Pedrinelli

DIPARTIMENTO CARDIO TORACICO, DIPARTIMENTO DI ENDOCRINOLOGIA E METABOLISMO ${ }^{1}$ UNIVERSITA’ DI PISA

ITALY

SHORT TITLE : ACE polymorphism and capillary permeability in hypertension

Reprint requests to: Prof Roberto Pedrinelli, Dipartimento Cardio Toracico, Università di Pisa, 56100 Pisa, Italy.

tel +39-050-996712, fax :+39-050-540522, E-mail: r.pedrinelli@med.unipi.it 
Dell'Omo et al: ACE polymorphism and capillary permeability in hypertension, 8/2/2006 CS2006/0165

\begin{abstract}
RATIONALE: A D/D polymorphism within the ACE gene increases the risk of microalbuminuria, a predictor of atherosclerotic vascular disease, in essential hypertension. It is unknown, however, whether that genetic profile is accompanied by disturbed macromolecular permeability of systemic capillary endothelium, possibly in the context of a generalized endothelial dysfunction. METHODS: The ACE gene polymorphism was determined by polymerase chain reaction in 79 never treated, uncomplicated hypertensive and 16 normotensive men as controls. Evaluation variables were the transcapillary escape rate of albumin (TERalb, the 1-hour decline rate of intravenous ${ }^{125}$ I-albumin, a measure of integrity of systemic capillary endothelium), albuminuria, forearm vasodilation to intra-arterial acetylcholine, an index of nitric oxide-mediated vasomotion, in addition to a series of sensitive parameters for albumin permeation (BP, metabolic status, smoking habits). RESULTS: Analyses were done by comparing D/D homozygotes vs grouped I/D and I/I subjects. TER $\mathrm{Alb}_{\mathrm{b}}$ was higher in $\mathrm{D} / \mathrm{D}$ hypertensives characterized also by higher albuminuria, more frequent microalbuminuria and comparable forearm responsiveness to intraarterial acetylcholine. 24-hr BP, fasting glucose and insulin, insulin sensitivity, smoking habits, metabolic parameters did not differ. TERalb and urine albumin values were positively associated. CONCLUSIONS: ACE D/D homozygosis associates with higher TERalb independent of several confounding factors in essential hypertensive men. That behavior may reflect noxious genetic influences on systemic vascular permeability, a critical control mechanism for atherogenesis in absence of grossly impaired nitric-oxide mediated arteriolar responsiveness. The parallel behavior of TERalb and albuminuria suggests some shared genetically mediated determinant of renal and systemic microvascular abnormalities in hypertension.

Key Words: ACE POLYMORPHISM, TRANSCAPILLARY ESCAPE RATE OF ALBUMIN, ALBUMINURIA, ENDOTHELIAL FUNCTION, HYPERTENSION

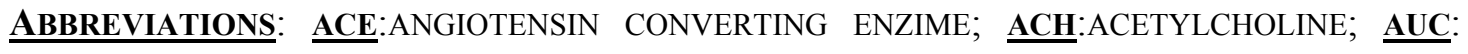

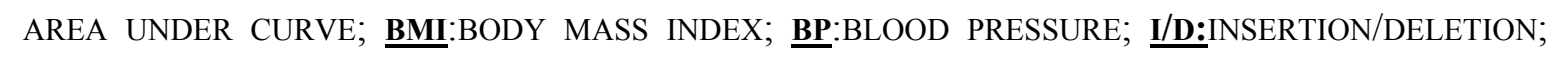
FBF:FOREARM BLOOD FLOW; HOMA-IR:HOMEOSTASIS MODEL ASSESSMENT OF INSULIN RESISTANCE; MA:MICROALBUMINURIA; METS: METABOLIC SYNDROME; NO:NITRIC OXIDE; OGTT:ORAL GLUCOSE TOLERANCE TEST; $\underline{\text { SNP:SODIUM NITROPRUSSIDE; TERALB:TRANSCAPILLARY }}$

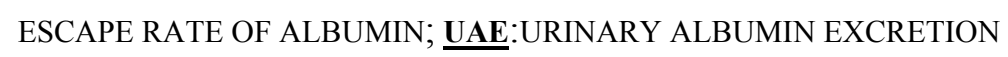


Dell'Omo et al: ACE polymorphism and capillary permeability in hypertension, 8/2/2006 CS2006/0165

\section{INTRODUCTION}

Consistent evidence supports the role of the Angiotensin I Converting Enzyme (ACE) Insertion/Deletion (I/D) polymorphism in the modulation of urinary albumin excretion (UAE) in non diabetic patients with essential hypertension. Several previous reports [e.g. 1-5], in fact, associated the presence of the D allele within the ACE gene with higher UAE and more frequent microalbuminuria (MA), a sign of subclinical renal damage and a predictor of atherosclerotic cardiovascular events [6] in hypertension. It is unknown, however, whether that noxious genetic influence on UAE, which may reflect more permeant renal glomeruli, is also accompanied by systemic changes in systemic permeability of capillary endothelium, a key determinant of endogenous defense against vascular injury and atherosclerosis $[7,8]$.

To assess that possibility, we measured the trans-capillary albumin escape rate (TERalb), a measure of the integrity of systemic capillary permeability [9], and its relationship with the ACE I/D genotype and UAE, in a group of non diabetic, never treated uncomplicated hypertensive men. To evaluate a possible coexistence of an abnormal function of arteriolar endothelium, we also investigated the association of that genotype with the endothelial-mediated vasodilator response to intra-brachial acetylcholine ( $\mathrm{ACH})$, a nitric oxide (NO) releasing agonist [10].

\section{MATERIAL AND METHODS}

\section{Subjects}

Seventy-nine never treated sedentary, Caucasian, apparently genetically unrelated hypertensive men and 16 normotensive men age-matched as a group participated in the study. Exclusion criteria were diabetes (fasting plasma glucose levels $>125 \mathrm{mg} / \mathrm{dl}$ and/or 2-hr postglucose load $\geq 200 \mathrm{mg} / \mathrm{dl}$ ), renal insufficiency (serum creatinine $>1.4 \mathrm{mg} / \mathrm{dl}$ ), proteinuria at the dipstick test and impaired cardiac function (ejection fraction $<50 \%$ ). In all, coexisting coronary and vascular disease were excluded through history, physical examination, routine blood chemistry, baseline EKG or, when indicated, treadmill test, echocardiography, carotid and lower limb echoDoppler sonography.

In accordance with the Declaration of Helsinki and institutional guidelines, the local Ethical Committee approved the protocol and subjects were aware of the investigational nature of the study and agreed to participate after signing a written consent.

MAIN EVALUATION VARIABLES

ACE genotype determination 
Dell'Omo et al: ACE polymorphism and capillary permeability in hypertension, 8/2/2006 CS2006/0165

Whole blood was collected in EDTA tubes and stored at $-20^{\circ} \mathrm{C}$ until extraction. Genomic DNA was extracted by manual saline extraction from lysed white blood cells as described elsewhere [11]. The polymorphic region in intron 16 of the ACE gene (17q23) was amplified by polimerase chain reaction (PCR) performed with $10 \mathrm{ng}$ DNA using 5 pmol of both primers: forward 5'-CTGGAGACCACTCCCATCCTTTCT-3' and reverse 5'-GATGTGGCC ATCACAT TCGTCAGAT-3'. Since the amplification of I allele is less efficient than D allele, the specificity of D/D genotyping was increased by amplifying again all D/D samples using a pair of primers specific for the insertion sequence (forward 5'-TGGGACCACAGCGCCCGCCATTAC-3' and reverse 5'-TCGCCAGCCCTCCCATGCC CATAA-3') in presence of DMSO 5\%. Two different operators (L.P. and D.L.) unaware of the patient clinical status read gels independently.

\section{TERalb}

TERalb studies were performed between 2.00 and $4.00 \mathrm{pm}$ after a 4 hour fast with patients withdrawing from tea, coffee, alcohol, tobacco from the early morning as previously described [12]. In short, ${ }^{125}$ I-labeled human serum albumin (6-8 $\mu$ Ci, 222-296 kBq, SARI-125 A-2, SORIN Biomedica) was obtained by electrolytic technique, a procedure that does not alter the biological behavior of albumin in vivo. Free ${ }^{125} 1$ was eluted by passage in a Sephadex G-25-M column (Column PD-10, Pharmacia), a purification step that reduced free ${ }^{125}$ I content in the injected dose to less than $1 \%$. Labeled albumin was injected after a 30 -min rest in the sitting position as a bolus, and blood samples taken from the contralateral arm every 5 min during the hour following the injection. Radioactivity was measured (Cobra $5000 \gamma$-counter, Packard) in duplicate in whole blood samples centrifuged for $10 \mathrm{~min}$ at $3000 \mathrm{~g}$ for $40 \mathrm{~min}$. Hematocrit (Coulter Counter 55, Coulter Electronics) was determined in each sample. Serum albumin was measured by immunonephelometry (Behring Laser Nephelometer System, Behring, interassay variation coefficient: $5.2 \%$ ).

\section{UAE}

Urinary albumin was measured by nephelometry (Behring Laser Nephelometer System, Behring) using a commercially available kit (Roche, Italy, $0.1 \mathrm{mg} / \mathrm{dl}$ detection limit). Intra- and inter-assay variation coefficients at different concentrations of urine albumin were: $2.7 \%$ and $3.2 \%$ $(0.3 \mathrm{mg} / \mathrm{dl}), 2.4 \%$ and $2.9 \%(1 \mathrm{mg} / \mathrm{dl}) 1.9 \%$ and $2.6 \%(10 \mathrm{mg} / \mathrm{dl}), 1.8 \%$ and $3.2 \%(30 \mathrm{mg} / \mathrm{dl})$ respectively. To minimize the confounding influence of daily physical activity and facilitate the collection procedure, urine was collected from $8 .{ }^{00}$ p.m. to $8 .{ }^{00}$ a.m. during three consecutive days. Urinary and serum creatinine was measured by standard colorimetric methods.

\section{Forearm infusion}


Dell'Omo et al: ACE polymorphism and capillary permeability in hypertension, 8/2/2006 CS2006/0165

Forearm studies ( $\mathrm{n}=66$ hypertensive patients and $\mathrm{n}=12$ normotensive controls) were performed in the morning in a quiet, air-conditioned room 24-48 hours apart from TERalb determination. Subjects were fasted and instructed to restrain from heavy exercise and to avoid smoking and emotional excitement from the day before the experiment. A 22-gauge polyethylene catheter (Angiocath, Becton Dickinson) was inserted into the right brachial artery, the arterial line connected to an infusion pump (Perfusor, Secura FT, Braun) and subjects were then allowed to rest for approximately 30 minutes. Total forearm blood flow (FBF) was measured by venous plethysmography with a strain-gauge apparatus (Hokanson, EC 5R Plethysmograph). Strands made of silastic tubing of $0.4 \mathrm{~mm} \mathrm{I.D.} \mathrm{and} 0.8 \mathrm{~mm}$ O.D filled with mercury were used. The gauge was applied on the arm, 5-6 cm distal to the elbow at a tension sufficient to keep the gauge in the same position throughout the experiment. Patient forearm was kept on a table, slightly flexed and inclined at about $45^{\circ}$ to the horizontal plane with the wrist and hand supported by sand bags. One minute before FBF determination, a pneumatic paediatric cuff was placed around the wrist and inflated to suprasystolic arterial blood pressure in order to exclude the hand vascular region. A second cuff was placed proximal to the plethysmograph and automatically inflated to a pressure of $40 \mathrm{mmHg}$ to allow FBF measurement according to the venous occlusion method. BP was measured every 5 minutes throughout the study at the contralateral arm by an automated device (NIBP KO 7267.004, Kontron Instruments). Further details of the method have been published elsewhere [13].

Fresh solutions of $\mathrm{ACH} \mathrm{HCl}$ (Miovisin $^{\mathrm{TM}}$, Farmigea, 7.5, 15 and $30 \mu \mathrm{g} / \mathrm{min}$, five minutes each), a nitric oxide releasing compound [10], and sodium nitroprusside (SNP, Nipride ${ }^{\mathrm{TM}}$, Malesci, used as an internal control for NO-independent mechanisms [14], 0.8, 1.6 and $3.2 \mu \mathrm{g} / \mathrm{min}$, five minutes each in syringes protected from light through aluminium foil were infused intra-arterially. Preliminary studies had shown that those infusion periods were sufficient to reach a plateau of FBF response without changes in systemic arterial pressure and contralateral FBF. Local administration of $\mathrm{ACH}$ and SNP was preceded and followed by saline infusion $(0.6 \mathrm{ml} / \mathrm{min})$. The infusion sequence was randomized and a 30-minute interval was left between the first and second drug administration.

\section{Ancillary parameters}

Office systolic and diastolic blood pressure (BP) was the mean of several indirect recordings. 24 hour BP $\left(08^{30}-08^{00}\right.$ A.M) was measured through an oscillometric monitor (Diasys Integra, Novacor).

OGTT (75 g glucose) was performed in the morning after an overnight fast. Upon baseline samples, specimens for plasma glucose and insulin were drawn 0.5, 1, 1.5 and 2 hours after administration of the glucose load. Plasma glucose was measured by the glucooxidase method 
Dell'Omo et al: ACE polymorphism and capillary permeability in hypertension, 8/2/2006 CS2006/0165

using a Beckman Glucose Analyzer I/I (Beckman Instruments), and plasma insulin by immunoradiometric assay (Biosource, no crossreactivity with human proinsulin) with an interassay variation coefficient of $5 \%$.

Total, high density (HDL) and low density lipoprotein (LDL) cholesterol, triglycerides were assessed in fasting conditions by enzymatic colorimetric techniques (Roche, Modular system).

Anthropometric measurements (height and weight) were made after each participant had removed his shoes and upper garments. Body weight was measured to the nearest $0.1 \mathrm{Kg}$ on a scale with attached height measure (SECA 207).

Smoking status was defined as active smokers vs non smokers, without distinction between former- and never smokers.

\section{Data processing}

Plasma ${ }^{125} \mathrm{I}$-albumin concentration $(\mathrm{cpm} / \mathrm{ml})$ was plotted on a semi-logarithmic scale, and the transcapillary escape rate $(\% / h)$ was calculated from the mono-exponential disappearance rate constant of the ${ }^{125} \mathrm{I}$ curve from 10 to $60 \mathrm{~min}$. Plasma volume $\left(\mathrm{ml} / 1.73 \mathrm{~m}^{2}\right)$ was determined by retropolation to zero time of the disappearance curve corrected for the injected dose of tracer obtained by weighing the syringes before and after the injection [12].

UAE ( $\mu \mathrm{g} / \mathrm{min}$ ) was the average of three consecutive overnight collections (mean variation coefficient of the triplets: $22 \%$ ). MA was defined as UAE $\geq 15 \mu \mathrm{g} / \mathrm{min}$, an accepted threshold for overnight collections [15]. Because of its skewed distribution, albuminuria was log-transformed to normalize its distribution. Creatinine clearance $\left(\mathrm{ml} / \mathrm{min} \times 1.73 \mathrm{~m}^{2}\right)$ was calculated according to standard formulae ${ }^{1}$

FBF (ml $100 \mathrm{ml}^{-1}$ forearm volume $\mathrm{min}^{-1}$ ) represents the mean of four-five determinations obtained over the last two minutes of each experimental period. Percent FBF changes from baseline were the evaluation variable.

OGTT data were summarised as the area under curve (AUC, trapezoidal rule) values. Insulin sensitivity was assessed through the homeostasis model assessment of insulin resistance (HOMAIR $)^{2}$ [16]. Increasing HOMA-IR values denote progression from normal to impaired insulin

\footnotetext{
1 [12-Hr URine Volume X URINe CREATININE]/SERUM CREATININE X 1.73/Body SURFACE AREA

${ }^{2}$ FASTING SERUM INSULIN [ $\mu$ U/ML] X FASTING PLASMA GLUCOSE [MMOL/L]/22.5
} 
Dell'Omo et al: ACE polymorphism and capillary permeability in hypertension, 8/2/2006 CS2006/0165

sensitivity. BMI was calculated as weight $/$ height $^{2}\left(\mathrm{Kg} / \mathrm{m}^{2}\right)$. Metabolic syndrome (MetS) was diagnosed according to the National Cholesterol Education Program (NCEP) Adult Treatment Panel (ATP) III [17] (elevated BP and at least 2 of the following: triglycerides $\geq 150 \mathrm{mg} / \mathrm{dL}, \mathrm{HDL}$ cholesterol $<40 \mathrm{mg} / \mathrm{dL}$, fasting plasma glucose $\geq 110 \mathrm{mg} / \mathrm{dL}, \mathrm{BMI}>30 \mathrm{Kg} / \mathrm{m}^{2}$ ).

\section{Statistics}

Proper ANOVA models and $\chi^{2}$ statistics tested the statistical significance of continuous and categorical parameters respectively. Intraindividual association between variables was tested by correlation coefficients analysis. The association of TERalb (coded as 1 for upper-quartile values and 0 for the three remaining ones, cut-off: $11.1 \% / \mathrm{hr}$ ) with the ACE D/I genotype and other continuous and categorical covariates was analyzed by multivariate logistic regression and odds ratios (ORs) and 95\% confidence interval (CI)s were used to estimate relative risks. Statistical significance was set at $\mathrm{p}<0.05$. Descriptive statistics were means \pm SD or geometric means (interquartile range) for skewed parameters.

\section{RESULTS}

As a whole, $42(45 \%)$ subjects showed a D/D genotype vs $42(45 \%)$ and $7(10 \%)$ with a I/D and I/I genotype respectively. Allelic distribution was in Hardy-Weinberg equilibrium (chisquare $<0.271, \mathrm{df}=1, \mathrm{p}>0.6$ ) and did not differ by blood pressure status (table 1). Because of their low number making separate statistical comparisons not meaningful, I/I subjects were grouped with I/D in statistical analyses. 
Dell'Omo et al: ACE polymorphism and capillary permeability in hypertension, 8/2/2006 CS2006/0165

\section{TERalb by ACE genotype}

Fasting and stimulated glucose and insulin, HOMA index, triglycerides, BMI, UAE was higher and MetS more frequent in hypertensive patients than normotensive controls (table 1). As compared with normotensive controls, TERalb was higher in hypertensive patients, either as a whole $(7.4 \pm 1.5 \% / \mathrm{hr}, \mathrm{n}=16$, vs $9.8 \pm 2.4 \% / \mathrm{hr}, \mathrm{n}=79, \mathrm{p}=0.0002)$ or stratified by ACE genotype (D/D: $7.0 \pm 2.0 \% / \mathrm{hr}, \mathrm{n}=6$ vs $10.4 \pm 2.7 \% / \mathrm{hr}, \mathrm{n}=36, \mathrm{p}=0.005 ; \mathrm{I} / \mathrm{D}+\mathrm{I} / \mathrm{I}: 7.8 \pm 1.1 \% / \mathrm{hr}, \mathrm{n}=10$ vs $9.3 \pm 2.1, \mathrm{n}=43$, $\mathrm{p}=0.03)$.

In the hypertensive sample, TERalb was higher $(\mathrm{p}=0.03)$ in $\mathrm{D} / \mathrm{D}$ homozygotes than $\mathrm{I} / \mathrm{D}+\mathrm{I} / \mathrm{I}$ subjects (figure 1) independent of age, BP levels, metabolic parameters, renal function and MetS frequency that matched closely in the two hypertensive subgroups (table 2). Hematocrit (I/D+I/I: $38.3 \pm 4.7 \%$ vs D/D: $39.5 \pm 8.3 \%$ ), serum albumin (I/D+I/I: $4.3 \pm 0.3$ vs D/D: $4.6 \pm 0.3 \mathrm{~g} / \mathrm{dl}$ ) and plasma volume (I/D+I/I: $2837.3 \pm 359.4$ vs D/D: $\left.2900.5 \pm 400.5 \mathrm{ml} / 1.73 \mathrm{~m}^{2}\right)$ did not differ.

When TERalb (as a dichotomized variable, cutoff: $11.1 \% / \mathrm{hr}$ ) was used as the dependent variable in a multivariate logistic regression model, the allelic odds ratio for $\mathrm{ACE} D / \mathrm{D}$ vs pooled D/I+II was 3.1 (95\% CI:1.1-7.5, p=0.04) after accounting for BP, LDL cholesterol, smoking status, presence of MetS, HOMA index.

\section{UAE and FBF responses by ACE genotype}

UAE (12.1 [16) vs 8.0(7.3), $\mathrm{p}=0.03)$ was higher and MA ( $42 \%$ vs $14 \%, \mathrm{p}=0.01)$ more frequent in $\mathrm{D} / \mathrm{D}$ hypertensive homozygotes in whom TERalb correlated positively with UAE $(\mathrm{r}=0.23$, $\mathrm{p}=0.03, \mathrm{n}=79$ ) but not office and $24 \mathrm{hr}$ BP, BMI, lipids, fasting and post-load plasma glucose and insulin, HOMA index. No correlation was found among normotensive controls (figure 2).

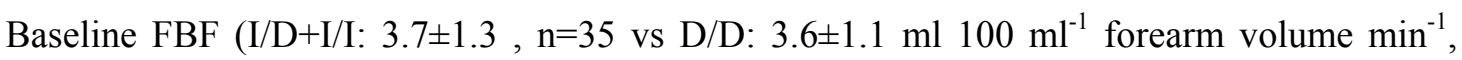
$\mathrm{n}=31$ ) and FBF responses to intra-brachial ACH and SNP did not differ by ACE genotype nor by hyper- vs normotensive status (figure 3)

\section{DISCUSSION}

The major and original finding of this cross-sectional genetic association study in never treated, uncomplicated hypertensive men was the independent association between ACE D/D homozygosis and faster TERalb. The data is consistent with a more deranged endothelial barrier function at the level of the systemic capillary circuit where most of the albumin permeation process takes place [7-9 for reviews]. Faster TERalb also coexisted with higher UAE suggesting some common genetically-mediated determinant for the abnormal behavior of renal and systemic 
Dell'Omo et al: ACE polymorphism and capillary permeability in hypertension, 8/2/2006 CS2006/0165

microvessels without evidence of NO-mediated endothelial dysfunction of systemic arterioles as assessed by forearm $\mathrm{ACH}$ stimulation.

\section{Pathophysiological implications}

Although the mechanistic links between the ACE polymorphism and a remote and complex phenotype such as capillary permeability cannot be elucidated, some plausible pathophysiological inferences may still be drawn from our data. First, whatever the underlying biological mechanism, the unfavorable influence of the ACE D/D genotype should not be seen as the cause but rather as a modulating factor for the defective systemic capillary permeability featuring human hypertension $[9$, $18,19]$ since irrespective of the ACE genotype, TERalb was higher in hypertensive patients than normotensive controls. One might also wonder whether the influence of the ACE D/D polymorphic extends to normotensive subjects but the limited number of control subjects included in our sample makes this point irrelevant. As a second point, the effect of a series of sensitive parameters for capillary albumin permeation, such as elevated BP [19] and LDL cholesterol [13], hyperinsulinemia [20], smoking habits [21], MetS phenotype [22], was likely exclude because of the homogeneous distribution of those parameters across ACE genotypes. Atherosclerotic vascular disease also affects TERalb [23] but our patients were carefully selected for absence of clinical vascular disease. Given the above considerations, other possibilities should be considered and renin angiotensin system activation appears as a plausible candidate mechanism. In fact, D/D homozygosis associates with higher circulating and tissue ACE levels [24], the rate limiting step in biologically active angiotensin II production [25], and also stimulates its local production [26]. In turn, angiotensin II increases oxidative stress through NADH/NADPH oxidase stimulation and, in concert with other mediators such as cytokines, NO, endothelin-1, prostaglandins and Rho-protein pathway, promotes vascular inflammation, increases capillary permeability and impairs endothelial function [27]. In that latter perspective, it was of interest the homogeneous forearm vasodilatory responsiveness to $\mathrm{ACH}$, a negative result in agreement with previous reports [28], suggestive of a different impact of the ACE genotypic variants on the capillary endothelial cell monolayer localized at the blood-vessel interface and endothelial cells covering resistance-sized forearm arterioles. Other possibilities cannot, however, be excluded including that, while TERalb measures systemic capillary permeability in basal conditions under the influence of several and interacting stimuli [7-9], the infused forearm model test only endogenous NO bio-availability in response to $\mathrm{ACH}$, a NO-releasing stimulus [10]. Furthermore, several and heterogeneous organs and tissues contribute to the transvascular albumin leakage determination while forearm responses represent a single, mainly muscular vascular bed. Finally, NOmediated relaxation needs only endothelial synthesis and diffusion of the substance to underlying smooth muscle cells, while capillary permeability requires a more complicated functional and structural interaction of cell junctions and extra-cellular matrix with endothelial cells [7-9]. On the 
Dell'Omo et al: ACE polymorphism and capillary permeability in hypertension, 8/2/2006 CS2006/0165

other hand, the preserved forearm responsiveness to locally infused $\mathrm{ACH}$, concordant with previous data in forearm [e.g. 29, 30], coronary [e.g. 31] and subcutaneous [e.g. 32] arterioles, shows that impaired endothelial-mediated vasodilatation is not universal among essential hypertensive patients but may rather develop at more complicated stages [33] or with longer duration of hypertensive disease [34]. However, we have no arguments in favor or against those possibilities, and, on the other hand, our study did not address those specific issues.

Comment also deserves the confirmed [1-5] association of higher UAE with the ACE D/D genotype, and more importantly in this context, its association with TERalb suggestive of some shared genetically-promoted determinant for the abnormal behavior of renal and systemic microvessels in ACE D/D hypertensive patients. Previous data showed that more albumin leaks through exaggeratedly permeant glomeruli characterized by decreased size- and charge-selectivity [35] and that albuminuria may reflect a generalized transvascular albumin leakiness in clinically healthy and diabetic subjects $[36,37]$. It should be noted, however, that the correlation between TERalb and UAE, albeit statistically significant, was rather weak in our present group. We also could not find a similar behavior in previous series [19], perhaps because the modulation of both parameters by multiple hemodynamic, metabolic and behavioral factors $[6,8]$ may obscure that link. It may not be irrelevant to note that higher UAE predicts cardiovascular events even in non hypertensive individuals [38] and MA is frequent among patients with mildly elevated BP, lean body size and no evidence of metabolic abnormalities and subclinical inflammation [39]. In those subsets, perhaps, genetic influences may be more influential on the renal and systemic microvascular system, an attractive possibility to be tested in the future.

\section{Limitations of the study}

A first obvious limitation of our study regards the strength of conclusions based upon a sample size of 79 patients. However, calculations accounting for effect size and allele frequency for predisposing alleles [40] indicate that, albeit limited, those numbers have a high statistical power to detect significant association when, as in our conditions, homozygous susceptibility genotype has a large biological impact (allelic $\mathrm{OR}=3.1$ ) and the prevalence of the susceptibility allele in the control group is high $(41 \%)$. On the other hand, we are aware that small initial studies frequently overestimate the true effect size thus increasing sample size requirements to thousands of cases and controls [e.g. 41], a goal difficult to be achieved dealing with a laborious parameter such as TERalb. For this reason, our present work should be seen as a biologically plausible, hypothesisgenerating contribution waiting for support from larger trials. Second, we studied an all-male hypertensive group and the influence of the ACE I/D polymorphism may differ by gender [42]. Third, our sample was recruited cross-sectionally making it difficult to assess cause-effect 
Dell'Omo et al: ACE polymorphism and capillary permeability in hypertension, 8/2/2006 CS2006/0165

relationships. Fourth, allelic association studies based on a single polymorphism in few candidate genes are subject to bias and confounding and we cannot exclude the influence of some unmeasured factors in our patients.

In conclusion, an $\mathrm{ACE} \mathrm{D} / \mathrm{D}$ homozygosis associates with a higher elevated trans-capillary escape rate of albumin and urine albumin levels suggesting a common origin for the two phenomena. That abnormal systemic capillary permeability may accelerate atherosclerotic vascular disease, for example by retaining more atherogenic lipoproteins in the subendothelial space and/or preventing their egress, a morbid evolution to which D/D subjects may be more exposed [43]. That conceivable but by now speculative hypothesis needs, however, to be tested prospectively. 
Dell'Omo et al: ACE polymorphism and capillary permeability in hypertension, 8/2/2006 CS2006/0165

\section{REFERENCES}

1. Pontremoli R, Sofia A, Tirotta A, Ravera M, Nicolella C, Viazzi F, Bezante GP, Borgia L, Bobola N, Ravazzolo R, Sacchi G and Deferrari G (1996) The deletion polymorphism of the angiotensin I-converting enzyme gene is associated with target organ damage in essential hypertension. J Am Soc Nephrol. 7, 2550-2558

2. Kario K, Kanai N, Nishiuma S, Fujii T, Saito K, Matsuo T, Matsuo M and Shimada K (1997) Hypertensive nephropathy and the gene for angiotensin-converting enzyme. Arterioscler Thromb Vasc Biol 17, 252-256.

3. Fernandez-Llama P, Poch E, Oriola J, Botey A, Coll E, Darnell A, Rivera F and Revert L (1998) Angiotensin converting enzyme gene $\mathrm{I} / \mathrm{D}$ polymorphism in essential hypertension and nephroangiosclerosis. Kidney Int. 53, 1743-1747

4. Redon J, Chaves FJ, Liao Y, Pascual JM, Rovira E, Armengod ME and Cooper RS. (2000) Influence of the I/D polymorphism of the angiotensin-converting enzyme gene on the outcome of microalbuminuria in essential hypertension. Hypertension 2000; 35[1 Pt 2]: 490-495.

5. Pedrinelli R, Dell'Omo G, Di Bello V, Penno G, Pucci L, Fotino C, Lucchesi D, Del Prato S, Dal Fiume C, Barlassina C and Cusi D (2006) $\alpha$-adducin and ACE polymorphisms in hypertension. Evidence for a joint influence on albuminuria. J Hypertens 24, 931-937

6. Pedrinelli R, Dell'Omo G, Di Bello V, Pontremoli R and Mariani M (2002) Microalbuminuria, an integrated marker of cardiovascular risk in essential hypertension. J Hum Hypertens 16, 79-89

7. Hinsbergh VWM (1997) Endothelial permeability for macromolecules. Mechanistic aspects of pathophysiological modulation. Arterioscler Thromb Vasc Biol 17, 1018-1023

8. Mehta D and Malik AB (2006) Signaling mechanisms regulating endothelial permeability. Physiol Rev. 86, 279-367

9. Parving HH (1975) Microvascular permeability to plasma proteins in hypertension and diabetes mellitus in man-on the pathogenesis of hypertensive and diabetic microangiopathy. Dan Med Bull $22,217-233$

10. Furchgott RF and Zawadzki JV (1980) The obligatory role of endothelial cells in the relaxation of arterial smooth muscle by acetylcholine. Nature 288, 373-376

11. Blin N and Stafford DN (1976) A general method for isolation of high molecular weight DNA from eukariotes. Nucleic Acid Res 3, 2303-2308 
Dell'Omo et al: ACE polymorphism and capillary permeability in hypertension, 8/2/2006 CS2006/0165

12. Nannipieri M, Pilo A, Rizzo L, Penno G, Rapuano A and Navalesi R (1995) Increased transcapillary escape rate of albumin in microalbuminuric type II diabetic patients. Diabetes Care $18,1-9$

13. Dell'Omo G, Penno G, Bandinelli S, Pedrinelli R and Mariani M (2000) Simvastatin, capillary permeability and endothelial-mediated vasomotion in atherosclerotic, hypercholesterolemic men. Clin Pharmacol Ther. 68, 427-434.

14. Bohme E, Graf H and Schultz G (1978) Effects of sodium nitroprusside and other smooth muscle relaxants on cyclic GMP-formation in smooth muscle and platelets. Adv Cyclic Nucleotide Res 9, $131-143$

15. Jensen JS, Feldt-Rasmussen B, Borch-Johnsen K, Jensen G \& The Copenhagen City Heart Study Group (1993) Urinary albumin excretion in a population based sample of 1011 middle aged nondiabetic subjects. Scand J Clin Lab Invest 53, 867-872

16. Mather KJ, Hunt AE, Steinberg HO, Paradisi G, Hook G, Katz A, Quon MJ and Baron AD. (2001) Repeatability characteristics of simple indices of insulin resistance: implications for research applications. J Clin Endocrinol Metab. 86, 5457-5464.

17. Executive Summary of the Third Report of The National Cholesterol Education Program [NCEP] Expert Panel on Detection, Evaluation, And Treatment of High Blood Cholesterol In Adults (Adult Treatment Panel III) (2001). JAMA 285, 2486-2497

18. Parving HH and Gyntelberg F (1973) Transcapillary escape rate of albumin and plasma volume in essential hypertension. Circ Res 32, 643-651

19. Pedrinelli R, Penno G, Dell'Omo G, Bandinelli S, Giorgi D, Di Bello V, Navalesi R and Mariani M (1999) Microalbuminuria and transvascular albumin leakage in essential hypertension. Hypertension 34, 491-495

20. Hilsted J and Christensen NJ (1992) Dual effect of insulin on plasma volume and transcapillary albumin transport. Diabetologia 35, 99-103

21. Jensen EW, Bryde Andersen H, Nielsen SL, Christensen NJ (1992): Long-term smoking increases transcapillary escape rate of albumin. Scand J Clin Lab Invest. 52, 653-656.

22. Dell'Omo G, Penno G, Pucci L, Mariani M, Del Prato S and Pedrinelli R (2004) Abnormal capillary permeability and endothelial dysfunction in hypertension with comorbid Metabolic Syndrome. Atherosclerosis 172, 383-389 
23. Pedrinelli R, Penno G, Dell'Omo G, Bandinelli S, Giorgi D, Di Bello V, Nannipieri M, Navalesi R and Mariani M (1998) Transvascular and urinary leakage of albumin in atherosclerotic and hypertensive men. Hypertension. 32, 318-323.

24. Rigat B, Hubert C, Alhenc-Gelas F, Cambien F, Corvol P and Soubrier F (1990) An insertion/deletion polymorphism in the angiotensin I-converting enzyme gene accounting for half the variance of serum enzyme levels. J Clin Invest 86, 1343-1346

25. Muller DN, Bohlender J, Hilgers KF, Dragun D, Costerousse O, Menard J and Luft FC (1997) Vascular angiotensin-converting enzyme expression regulates local angiotensin II. Hypertension $29,98-104$

26. Ueda S, Elliott HL, Morton JJ and Connell JM (1995) Enhanced pressor response to angiotensin I in normotensive men with the deletion genotype [DD] for angiotensin-converting enzyme. Hypertension 25, 1266-1269

27. Ruiz-Ortega M, Esteban V, Ruperez M, Sanchez-Lopez E, Rodriguez-Vita J, Carvajal G and Egido J. (2006): Renal and vascular hypertension-induced inflammation: role of angiotensin II. Curr Opin Nephrol Hypertens. 15, 159-166.

28. Rossi GP, Taddei S, Virdis A, Ghiadoni L, Albertin G, Favilla S, Sudano I, Pessina AC and Salvetti A (2001) Exclusion of the ACE D/I gene polymorphism as a determinant of endothelial dysfunction. Hypertension. 37, 293-300

29. Cockcroft JR, Chowienczyk PJ, Benjamin N and Ritter JM (1994) Preserved endotheliumdependent vasodilatation in patients with essential hypertension. N Eng J Med 330, 1036-1040

30. Bruning TA, Chang PC, Hendriks MGC, Vermeij P, Pfaffendorf M and Van Zwieten PA (1995) In vivo characterization of muscarinic receptor subtypes that mediate vasodilatation in patients with essential hypertension. Hypertension 26, 70-77

31. Zeiher AM, Drexler H, Saurbier B and Just H (1993) Endothelium-mediated coronary blood flow modulation in humans. Effect of age, atherosclerosis, hypercholesterolemia and hypertension. $\mathrm{J}$ Clin Invest 92, 652-662

32. James MA, Watt PA, Potter JF, Thurston H and Swales JD (1997) Endothelial function in subcutaneous resistance arteries from elderly hypertensive and normotensive subjects. Clin Sci 92, $139-145$

33. Perticone F, Ceravolo R, Pujia A, Ventura G, Iacopino S, Scozzafava A, Ferraro A, Chello M, Mastroroberto P, Verdecchia P and Schillaci G. (2001) Prognostic significance of endothelial dysfunction in hypertensive patients. Circulation. 104, 191-196. 
34. Park JB and Schiffrin EL. (2001) Small artery remodeling is the most prevalent [earliest?] form of target organ damage in mild essential hypertension. J Hypertens. 19, 921-930

35. Jensen JS, Borch-Johnsen K, Deckert T, Deckert M, Jensen G and Feldt-Rasmussen B (1995) Reduced glomerular size- and charge-selectivity in clinically healthy individuals with microalbuminuria. Eur J Clin Invest. 25, 608-614.

36. Jensen JS, Borch-Johnsen K, Jensen G and Feldt-Rasmussen B (1995) Microalbuminuria reflects a generalized transvascular albumin leakiness in clinically healthy subjects. Clin Sci 88, 629-633

37. Knudsen ST, Bek T, Poulsen PL, Hove MN, Rehling M and Mogensen CE (2002). Macular edema reflects generalized vascular hyperpermeability in type 2 diabetic patients with retinopathy. Diabetes Care 25, 2328-2334

38. Arnlov J, Evans JC, Meigs JB, Wang TJ, Fox CS, Levy D, Benjamin EJ, D'Agostino RB and Vasan RS. (2005) Low-grade albuminuria and incidence of cardiovascular disease events in nonhypertensive and nondiabetic individuals: the Framingham Heart Study. Circulation. 112, 969975

39. Pedrinelli R, Dell'Omo G, Di Bello V, Pellegrini G, Pucci L, Del Prato S and Penno G. (2004) Low-grade inflammation and microalbuminuria in hypertension. Arterioscler Thromb Vasc Biol. 24, 2414-2419.

40. Hattersley AT and McCarthy MI (2005) What makes a good genetic association study? Lancet. $366,1315-1323$.

41. Keavney B, McKenzie C, Parish S, Palmer A, Clark S, Youngman L, Delepine M, Lathrop M, Peto R and Collins R (2000) Large-scale test of hypothesised associations between the angiotensin-converting-enzyme insertion/deletion polymorphism and myocardial infarction in about 5000 cases and 6000 controls. International Studies of Infarct Survival [ISIS] Collaborators. Lancet. 355, 434-442.

42. O'Donnell CJ, Lindpaintner K, Larson MG, Rao VS, Ordovas JM, Schaefer EJ, Myers RH and Levy D (1998) Evidence for association and genetic linkage of the angiotensin-converting enzyme locus with hypertension and blood pressure in men but not women in the Framingham Heart Study. Circulation 97, 1766-1772.

43. Butler R (2000) The DD-ACE genotype and cardiovascular disease. Pharmacogenomics 1, 153167 
Dell'Omo et al: ACE polymorphism and capillary permeability in hypertension, 8/2/2006 CS2006/0165

\section{FIGURES}

Figure 1 : TERalb by ACE genotype in hypertensive men. Data reported as Box-and-whisker plots $^{3} . * \mathrm{p}=0.03$. For further details see text.

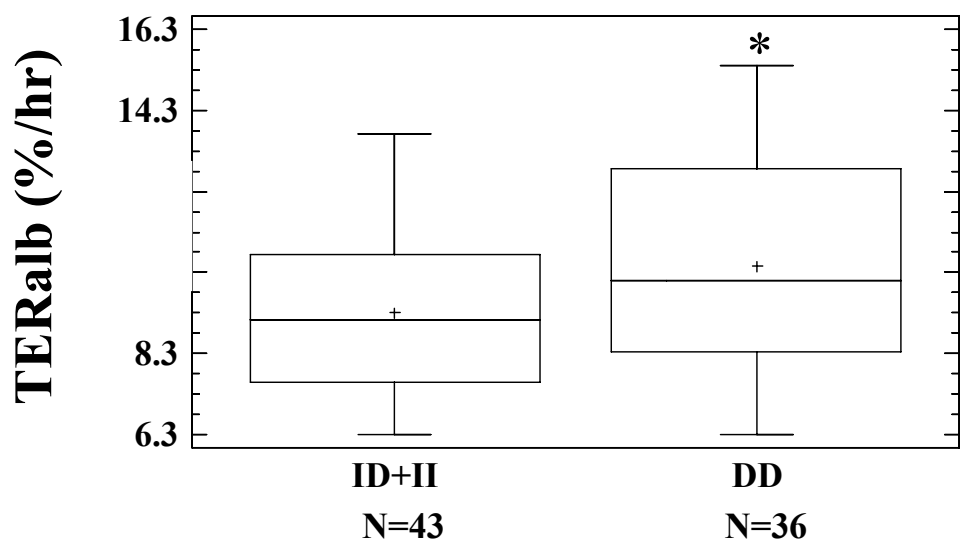

${ }^{3}$ Box-and-Whisker plot: The central box encloses the middle 50 percent of the data; the horizontal line inside the box represents the median and the mean is plotted as a cross. Vertical lines [whiskers] extend from each end of the box and cover four interquartile ranges. 
Dell'Omo et al: ACE polymorphism and capillary permeability in hypertension, 8/2/2006 CS2006/0165

Figure 2: The relationship between TERalb and urinary albumin excretion [UAE, log-scale] in hypertensive patients $[\mathrm{n}=79, \square]$. For a comparison, the scatterplot also show data obtained in control subjects $[\mathrm{n}=16, \bullet]$. For statistics see text.

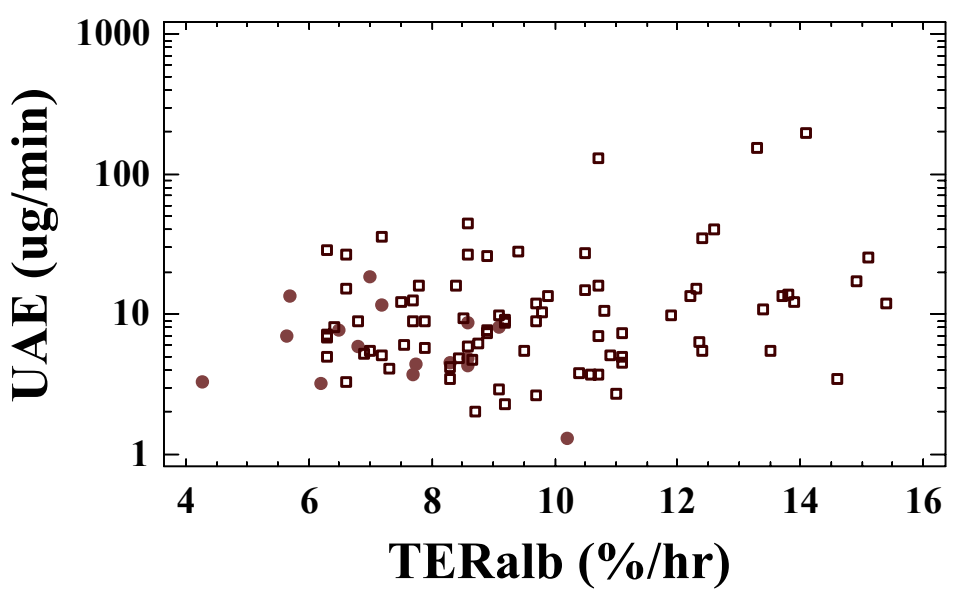


Dell'Omo et al: ACE polymorphism and capillary permeability in hypertension, 8/2/2006 CS2006/0165

Figure 3: FBF responses to ACH and SNP by ACE genotype in hypertensive patients. As a standard of comparison, the figure also reports data for control subjects $[\square$ Controls, $n=12$; $\mathrm{I} / \mathrm{D}+\mathrm{I} / \mathrm{I}, \mathrm{n}=35 ; \mathrm{D} / \mathrm{D}, \mathrm{n}=31]$. Means $\pm \mathrm{SD}$. For further details see text.

ACH-MEDIATED VASODILATION

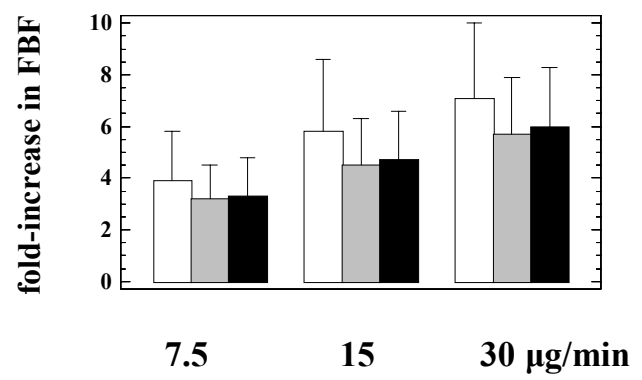

SNP-MEDIATED VASODILATION

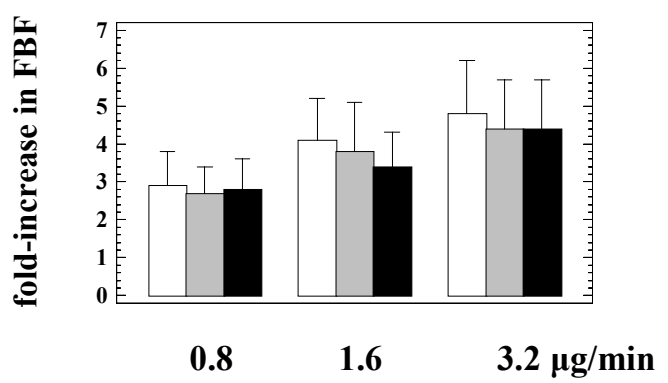


Dell'Omo et al: ACE polymorphism and capillary permeability in hypertension, 8/2/2006 CS2006/0165

\section{TABLES}

Table 1: Comparison of hypertensive patients and normotensive controls [Means \pm SD or geometric means [interquartile range]]. For statistics, definitions and abbreviations see text.

\begin{tabular}{|c|c|c|c|}
\hline VARIABLES & $\begin{array}{l}\text { CONTROLS } \\
N=16\end{array}$ & $\begin{array}{l}\text { HYPERTENSIVES } \\
N=79\end{array}$ & P VALUE \\
\hline Age [yrs] & $47 \pm 12$ & $48 \pm 10$ & NS \\
\hline DD/ID/II & $6 / 8 / 2$ & $36 / 36 / 7$ & NS \\
\hline Clear $_{\text {creat }}\left[\mathrm{ml} / \mathrm{min} * 1.73 \mathrm{~m}^{2}\right]$ & $104 \pm 29$ & $110 \pm 36$ & NS \\
\hline Active smokers & $7 / 16[43 \%]$ & $26 / 79[33 \%]$ & NS \\
\hline Office systolic BP [mm Hg] & $126 \pm 10$ & $149 \pm 14$ & $\mathrm{~N} / \mathrm{A}$ \\
\hline Office diastolic BP [mm Hg] & $76 \pm 6$ & $96 \pm 11$ & N/A \\
\hline 24 hr systolic BP [mmHg] & $121 \pm 7$ & $137 \pm 16$ & $\mathrm{~N} / \mathrm{A}$ \\
\hline 24-hr diastolic BP [mmHg] & $75 \pm 6$ & $88 \pm 9$ & N/A \\
\hline Fasting plasma glucose [mg/dL] & $88 \pm 12$ & $98 \pm 11$ & $\mathrm{p}=0.002$ \\
\hline Glucose AUC $C^{0-120 \min }\left[\left[\mathrm{mg} / \mathrm{dl} \times 2 \mathrm{~h}^{-1}\right] \times 10^{-3}\right]$ & $14.3 \pm 2.1$ & $16.1 \pm 3.1$ & $\mathrm{p}=0.02$ \\
\hline Fasting insulin $[\mu \mathrm{U} / \mathrm{ml}]$ & $7.7[2.3]$ & $12.3[10.4]$ & $\mathrm{p}=0.004$ \\
\hline Insulin $A \mathrm{UC}^{0-120 \mathrm{~min}}\left[\left[\mu \mathrm{U} / \mathrm{ml} \times 2 \mathrm{~h}^{-1}\right] \times 10^{-3}\right]$ & $5.3[6.1]$ & $12.3[10.4]$ & $\mathrm{p}=0.014$ \\
\hline HOMA-IR [Units] & $1.7[0.9]$ & $2.9[2.8]$ & $\mathrm{p}=0.0013$ \\
\hline HDL cholesterol [mg/dL] & $46 \pm 9$ & $45 \pm 14$ & NS \\
\hline Serum triglycerides $[\mathrm{mg} / \mathrm{dL}]$ & $94[42]$ & $160[124]$ & $\mathrm{p}=0.004$ \\
\hline $\mathrm{BMI}\left[\mathrm{Kg} / \mathrm{m}^{2}\right]$ & $24.1 \pm 1.7$ & $27.3 \pm 3$ & $\mathrm{p}=0.0001$ \\
\hline MetS & $0 / 16[0 \%]$ & $32 / 79[41 \%]$ & $\mathrm{p}=0.005$ \\
\hline Total cholesterol [mg/dL] & $193 \pm 47$ & $208 \pm 42$ & NS \\
\hline LDL cholesterol [mg/dL] & $127 \pm 43$ & $126 \pm 38$ & NS \\
\hline
\end{tabular}


Dell'Omo et al: ACE polymorphism and capillary permeability in hypertension, 8/2/2006 CS2006/0165

Table 2 : Comparisons by ACE genotype in hypertensive patients [Means \pm SD or geometric means [interquartile range]]. For definitions and abbreviations see text. None of the parameters showed significant differences.

\begin{tabular}{|c|c|c|}
\hline VARIABLES & $\begin{array}{l}I D+I / I \\
N=43\end{array}$ & $\begin{array}{l}D / D \\
N=36\end{array}$ \\
\hline Age [yrs] & $47 \pm 9$ & $49 \pm 11$ \\
\hline D Allele frequency [\%] & $42 \%$ & $100 \%$ \\
\hline Clear $_{\text {creat }}\left[\mathrm{ml} / \mathrm{min}^{*} 1.73 \mathrm{~m}^{2}\right]$ & $106[35]$ & $110[28]$ \\
\hline Active smokers & $16 / 43[37 \%]$ & $10 / 36[28 \%]$ \\
\hline Office systolic BP [mm Hg] & $149 \pm 14$ & $151 \pm 16$ \\
\hline Office diastolic BP [mm Hg] & $96 \pm 11$ & $96 \pm 9$ \\
\hline 24 hr systolic BP [mmHg] & $138 \pm 17$ & $136 \pm 14$ \\
\hline 24-hr diastolic BP [mmHg] & $88 \pm 10$ & $88 \pm 8$ \\
\hline Fasting plasma glucose $[\mathrm{mg} / \mathrm{dL}]$ & $99 \pm 11$ & $96 \pm 11$ \\
\hline Glucose $A U C^{0-120 \min }\left[\left[\mathrm{mg} / \mathrm{dl} \times 2 \mathrm{~h}^{-1}\right] \times 10^{-3}\right]$ & $16.7 \pm 2.7$ & $15.1 \pm 3.2$ \\
\hline Fasting insulin $[\mu \mathrm{U} / \mathrm{ml}]$ & $13.9[2.5]$ & $10.4[7]$ \\
\hline Insulin $A \mathrm{UC}^{0-120 \min }\left[\left[\mu \mathrm{U} / \mathrm{ml} \times 2 \mathrm{~h}^{-1}\right] \times 10^{-3}\right]$ & $13.9[7.4]$ & $7.4[8.2]$ \\
\hline HOMA-IR [Units] & $3.3[3.3]$ & $2.6[1.7]$ \\
\hline HDL cholesterol [mg/dL] & $45 \pm 15$ & $44 \pm 12$ \\
\hline Serum triglycerides $[\mathrm{mg} / \mathrm{dL}]$ & 159 [147] & $151[113]$ \\
\hline $\mathrm{BMI}\left[\mathrm{Kg} / \mathbf{m}^{2}\right]$ & $27.3 \pm 3$ & $27.4 \pm 3.1$ \\
\hline MetS & $20 / 43[47 \%]$ & $12 / 36[33 \%]$ \\
\hline Total cholesterol [mg/dL] & $208 \pm 42$ & $213 \pm 37$ \\
\hline LDL cholesterol [mg/dL] & $126 \pm 38$ & $134 \pm 32$ \\
\hline
\end{tabular}

